\title{
STUDY OF INJURIES IN MARTIAL ARTS
}

\author{
Anna Nikolova \\ National Sports Academy "Vassil Levski”, Sofia, Bulgaria
}

\begin{abstract}
Methodology: The aim of the study is to characterize the injury types among martial arts contestants from Bulgaria. The study includes 98 contestants whose' average age is $22,5 \pm 5$, and on average have competed for 8.6. $\pm 0,5$, and are part of a national team in one of the following sports: judo, jiu jitsu, karate and taekwondo. The study was conducted in the form of a survey in retrospective plan.

Results: The athletes that took the survey claim to have had collectively 292 injuries during their competitive career. $10,2 \%(n=10)$ haven't had any type of injury. Furthermore, 13,2\% $(n=13)$ have had more than 8 different injuries. Among the Judo contestants $30 \%(n=12)$, and jiu jitsu 45\% $(n=18)$ the injuries happen more often during training, while among taekwondo contestants the injuries are spread more equally between training and contest'.

The most common injuries are sprains $-17,4 \%(n=36)$ followed by strains $-12,1 \%(n=25)$, lesion fiber of tendon-11\% $(n=23)$ and fractures $9.7 \%(n=20)$.

Among 31\% (n=91) the injuries are located in the upper limbs from which 8,2\% $(n=24)$ and $7,8 \%(n=23)$ are located in the shoulder area and elbow. The injuries in 33\% $(n=97)$ are located in the lower limbs predominantly in the knee area $11,6 \%(n=34)$.

According the surveyed athletes the most common reason for an injury is direct hit from the opponent received during combats $45 \%(n=36)$.

Conclusion: The acquired data from the study determines that the predominate injuries among contestants in martial arts are soft tissue injuries, received from direct hit from opponent during combat. There are no established differences in the frequency or type of injury between the various sports.
\end{abstract}

Key words: Martial arts, injuries, Judo, Jiu jitsu, Karate, Taekwondo.

\section{INTRODUCTION}

Healthier lifestyle gains more and more followers. This covers not only environmentally conscious diet but also more movement and more engage- $j$ ment in different sports. One of the most popular ones are the eastern martial arts. The martial art teaching focuses not only around different defense methods, strength, coordination, balance and elasticity but also focuses on discipline and respect. (Zetaruk et all., 2005).

As in all sports the participants cannot be guaranteed that there won't be any injuries. Through the years the frequency of injuries has been a common study matter for many different authors. There was even introduced The Orchad sport injury classification system /OSICS-8/ which was further improved in 2002 as ICD-10, Australian Modification /ICD10-AM/. (Rae et all,2005)

Unfortunately, the writers have not gotten to a consensus for precise definition of an injury. In our study we have adopted the definition of Dimitrova D. that this would be an injury that happens during sports exercise. (Dimitrova, 2017). Also, as definition of a severity of injury we adopted the classification of Manzato (Manzato et all, 2017) that light injuries are the ones which result in training absence in less than 7 days, medium injuries in between 7 and 28 days and severe injuries in more than 28 days.

Some authors point out that in sports where gripping is predominant, the type of injuries that primarily occur are sprains and strains and in semi-contact sports, injuries from impact are predominant.

Aim: We set out to investigate the frequency and distribution of injuries among practitioners of the following martial arts - judo, jiu jitsu, karate, and taekwondo.

\section{METHODOLOGY}

A self-administered study was conducted among 98 elite athletes from the Bulgarian national judo team, jiu jitsu, karate and taekwondo. The conducted study was anonymous. The questions were 
formed following the ethical standards dictated from the Helsinki's ethical declaration pandect and the National sport academy's ethical pandect. The questions were divided into two parts. First part focused on characteristics about the athlete's age, height, weight and competitive class. Furthermore, it included questions about the competitions they participated in, ranking, way of training and recovering activities. The second part was focused on the types of injuries and reasons that might lead to them, according to the surveyed, as well as types of treatments that they undertook. And absence length from training and competition, the participants took in order to recover from an injury. The data were processed using statistically-descriptive statistics, frequency and correlation analysis.

\section{RESULTS}

In the study participated athletes, from the national teams of judo, jiu jitsu, karate and taekwondo with mean age $22.5 \pm 5$ years and mean sporting experience of $8,6 \pm 0,5$ years. The participants were divided into two groups - Group one: judo and jiu jitsu, because of the prevalence of grips in the fights. And group two: karate and taekwondo, due to the prevalence of strikes and semi contact. Number and average age of athletes, total hours spent in training, as well as fitness and warm-up time and stretching time are presented in Table 1. As the table visualizes the dedicated that dates do not differ much from the dedicated dates! time of the athletes described in the study of writers (Minghelli, Isidoro, 2016; Oliveira,Pereira, 2008).

Table 1. Modifiable factors

\begin{tabular}{|c|c|c|}
\hline COLUMN1 & JUDO, JIU JITSU & TAEKWONDO, KARATE \\
\hline MEAN & 65 & 33 \\
\hline MIDDLE-AGED & $23,5 \pm 6,1$ & $20 \pm 3,5$ \\
\hline SPORTS EXPERIENCE & $8,3 \pm 6,2$ & $7,9 \pm 5$ \\
\hline TRAINING HOURS/WEEKS & $12 \pm 7,6$ & $7,6 \pm 5,4$ \\
\hline WARM UP (MIN.) & $21,7 \pm 7,8$ & $24 \pm 8,6$ \\
\hline STRETCHING (MIN.) & $11,5 \pm 7,1$ & $10,6 \pm 7,5$ \\
\hline
\end{tabular}

Among $11 \%$ of judo and jiu jitsu practitioners have not reported any injury, compared to $9 \%$ of karate and taekwondo practitioners. With more than 3 injuries among judo and jiu jitsu takes $12,3 \%$ and $15,1 \%$ among karate and taekwondo.
$46 \%$ of the injuries among judo and jiu Jitsu contestants occur mostly during training. Whereas $30 \%$ of Karate and Taekwondo contestants are equally injured both during training and competition. (Figure 1)

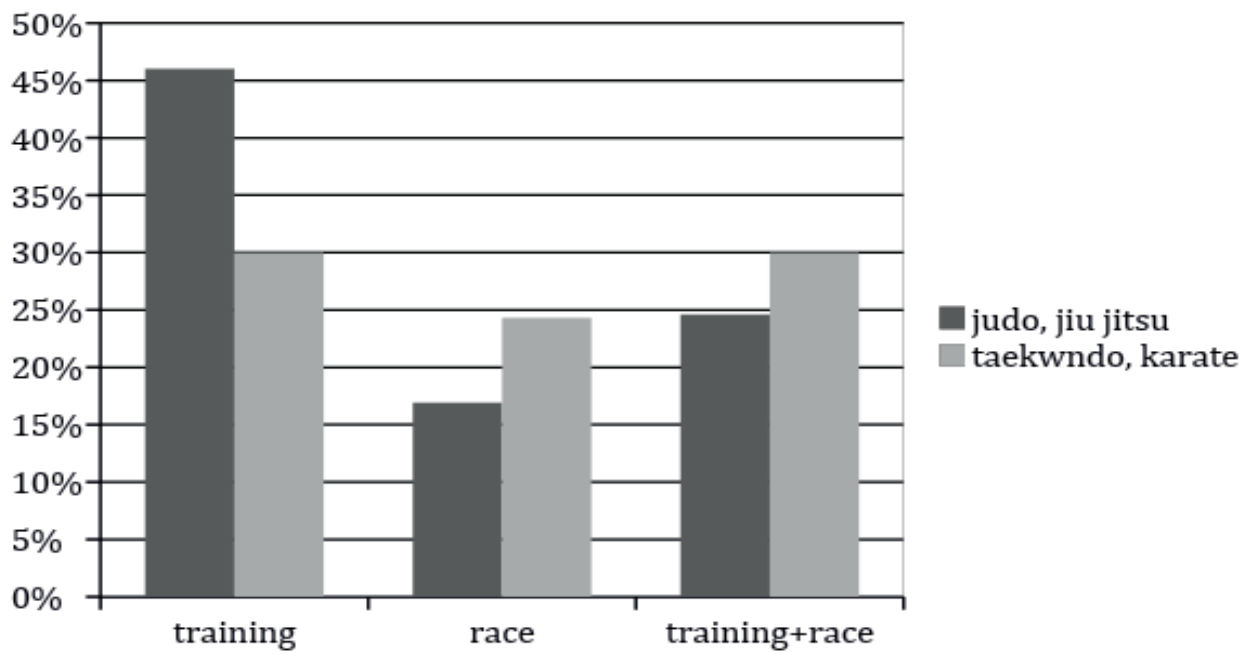

Figure 1. Time of injuries

Some authors point out bigger risk for injury (Al- 2018) during contests and others (Del Vecchio et bert, 2017; Pocecco et all, 2013; Trajković et all, all, 2017; Minghelli, Isidoro, 2016; Oliviera, Perei- 
ra, 2008) during training. We believe that there is During training most injuries get judo and no sufficient difference among the competitors be- jiu jitsu athletes - $43 \%$ usually during rancause the study covers a long period of time and dori. Whereas - 33\% of karate and taekwonthe athletes report injuries from different periods do athletes get injuries from direct impact. of their career.

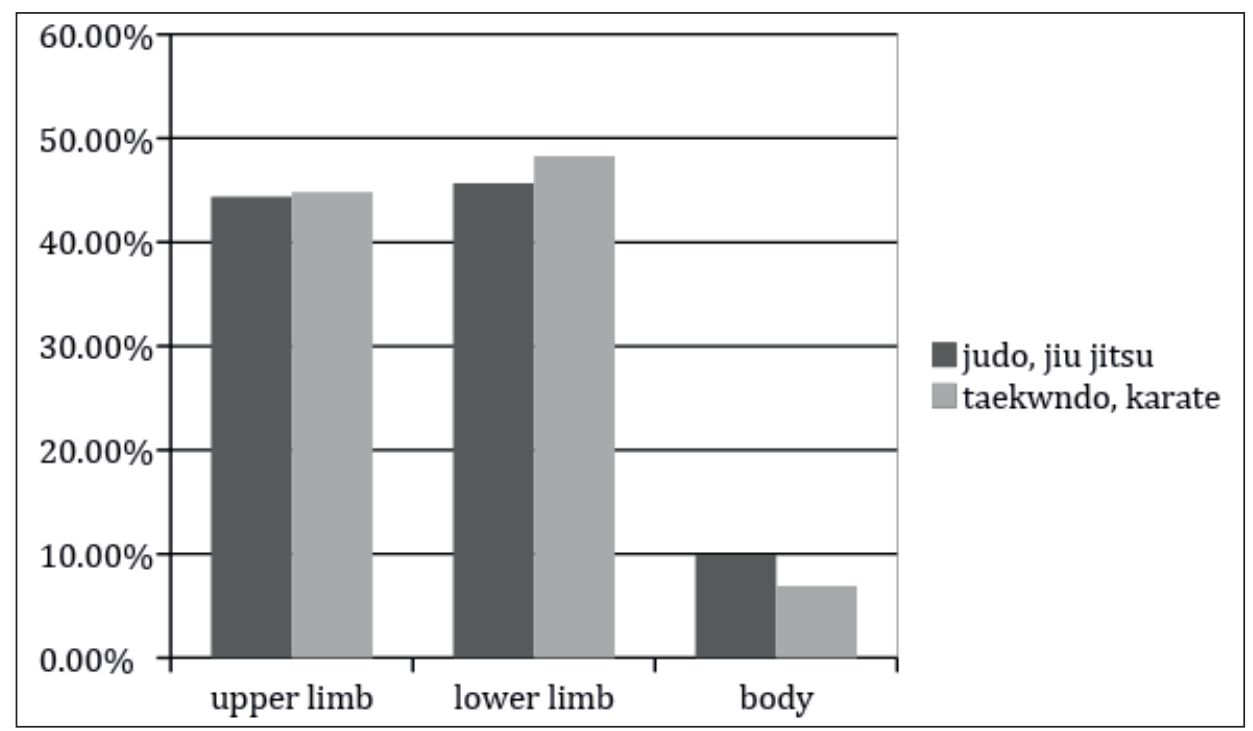

Figure 2. Distribution of injuries on the body

Altogether for their entire sports career 98 athletes have gotten 292 different injuries in total. The most common are the following injuries: from all types of sports equally predominant injuries in upper and lower limbs. (Figure 2).
In terms of type, the most common are soft tissue injuries such as tears of fibers $-12.6 \%$ in judo and jiu jitsu - and 5.8\% in taekwondo and karate followed by contusion, distortion and fractures. (Figure 3)

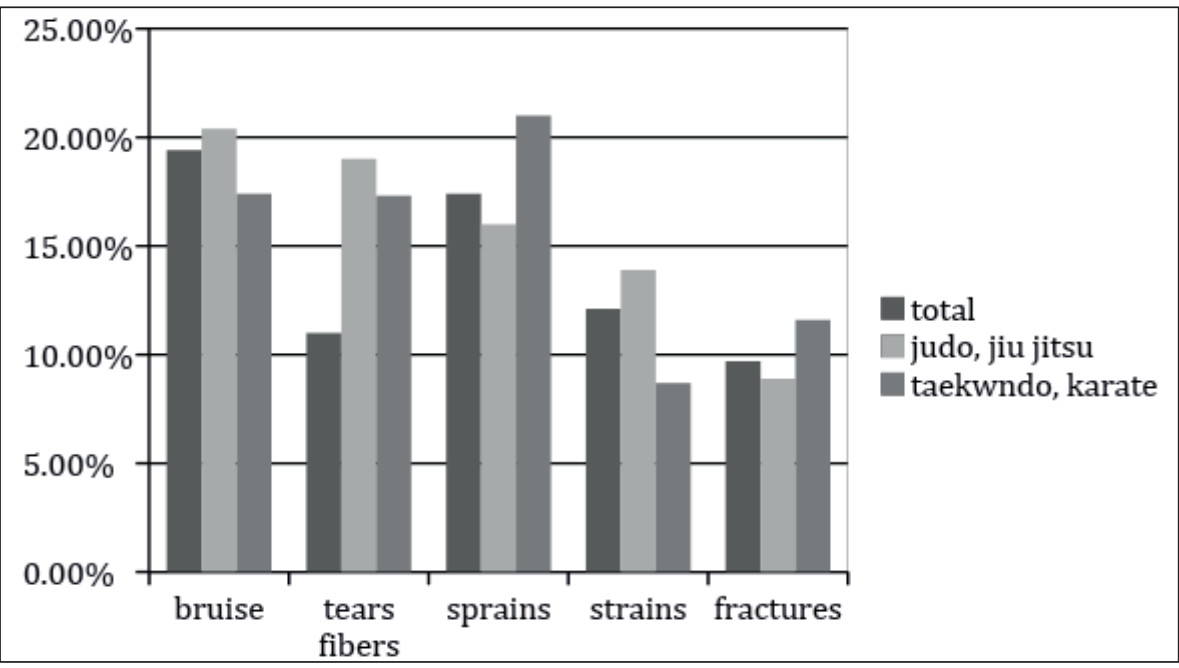

Figure 3. Type of injuries

The severity of the injuries we can categorize in um injuries for absence between 8 and 28 days and three categories: light, medium and severe, based severe injuries for more than 28 days. With severe on absence taken from a sport activity. According injuries are $27,5 \%$ and $14,2 \%$ among judo and jiu to the Mazato (Manzato et all, 2017) classification, jitsu while among taekwondo and karate the severe as follows: light injuries for absence $\leq 7$ days, medi- injuries are $-11.2 \%$. (Figure 4) From sport activi- 
ties had to be absent from judo and jiu jitsu 12,6\%. While in taekwondo and karate - 22,4\%

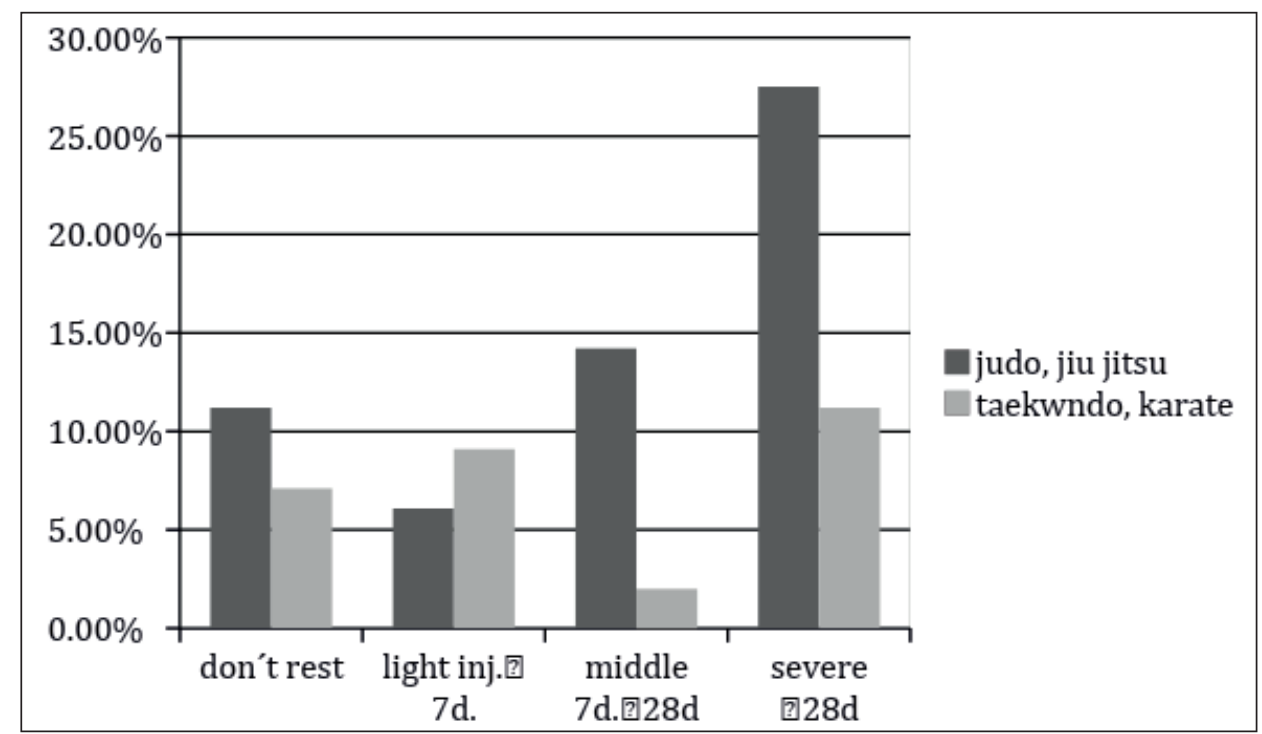

Figure 4. Severity of the injuries

The only treatment that was necessary for recovery, $17,3 \%$. The percentage was equal in all sports of the was rest for $12,6 \%$ of judo and jiu jitsu athletes and athletes that needed cast or required surgery. (Fig$22,4 \%$ among taekwondo and karate. As follows: ure 5)

physiotherapy $8,9 \%$, to $11,2 \%$. Medication $9,5 \%$ to

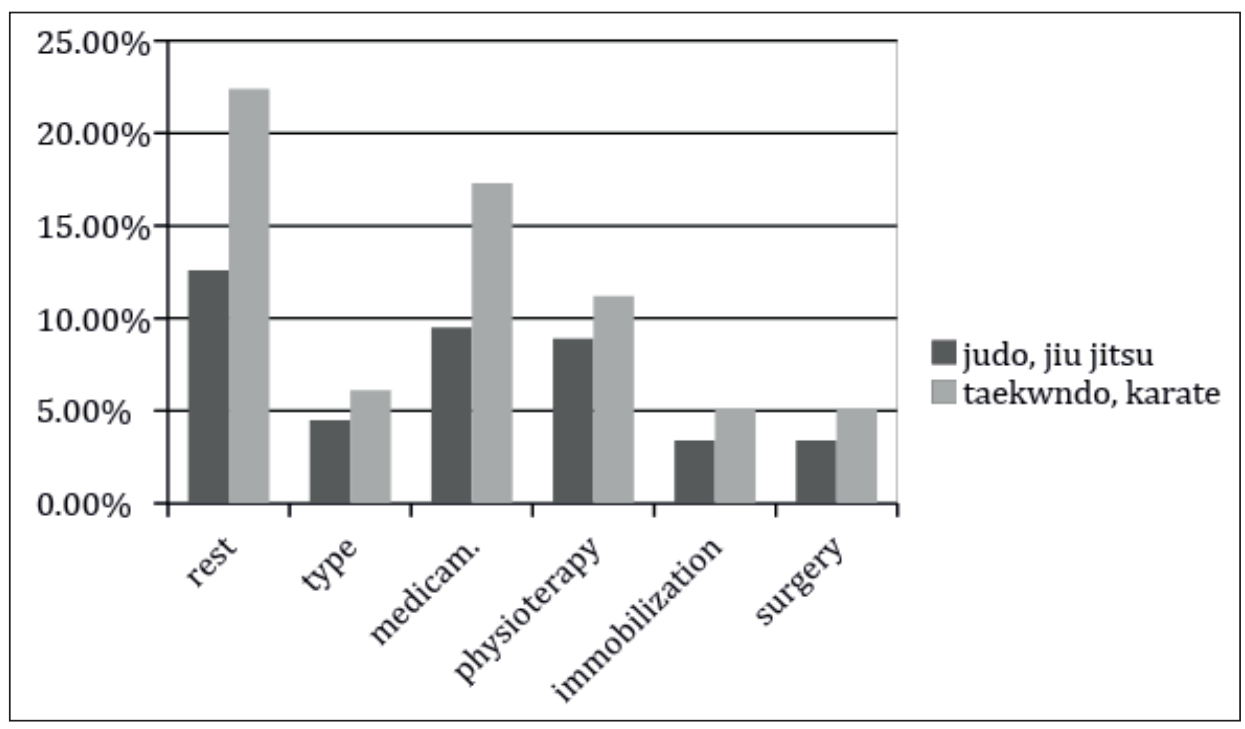

Figure 5. Treatment

\section{CONCLUSION}

We did not notice a significant difference in the risk of injuries with the increase of sports experience, as some authors have pointed out.

Furthermore, we did not notice an increase in injuries with the increase of training hours.

In martial arts the injuries that predominate are: soft tissue, torn muscles tissue and torn tendon fol- lowed by contusions and distortions.

In martial arts the competitors injure equally upper and lower limbs.

Most of the injuries heal primarily with resting. Whereas the competitors who needed cast was only $3,4 \%$ and in karate and taekwondo - 5,9\%. Also, the number of competitors who required surgery is the same as casted ones, in the researched sports. 
In days of absence from competition, medium and severe injuries are prevalent in judo and jiu jitsu and severe injuries in karate and taekwondo.

\section{ACNOWLEDGEMENT}

I would like to thank all the athletes who have taken the time to complete the surveys in order to conduct this research.

\section{REFERENCES}

Albert, M. (2017). Examination of the impact of medicinal massage combined with deep occurrence in the healing process of patients with world write. International Journal Knowledge in Scientific Papers, Vol 19, 4, Skopje. pp. 1467-1473, ISSN 1857-923 X.

Burke, D.T., Barfoot K. et al. (2003). Effect of implementation of safety measures in taekwondo competition, $\mathrm{Br} J$ Sports Med. 2003;37:401-404

Cynarski, WJ, Kudlacz M. (2008). Injuries in martial arts and combat sports-a comparative study. Arh Budo; 4; 91-73.

Del Vecchio, F.B., Farias, C.B. et al. (2017). Injuries in martial arts and combat sports: Prevalence, characteristics and mechanisms, https//doi.org/10.1016/j.scispo.2018.02.003

Dimitrova, D. (2018). Sportna medicina. Avangard Prima, Sofia, 2018, ISBN 978-619-160-904-8 19. // Димитрова Д. (2018). Спортна медицина, Авангард Прима, София, ISBN 978-619-160-904-8 19.

Engebretsen L., Soligard T.Steffen K.,et all. (2013). Sports injuries and illnesses during the London Summer Olympic Games 2012. Br J Sports Med;47;407-14

James, F. Scoggin, III, MD, et al. (2014). Assessment of Injuries During Brazilian Jiu-Jitsu Competition, The Orthopedic Journal of Sports Medicine, 2(2), 232596 7114522184 DOI: $10.1177 / 2325967114522184$

Manzato, A.L.G. et al. (2017). Musculoskeletal injuries in judo practitioners, DOI: 10.1590/18092950/16325024022017

Minghelli, B.and Isidoro, R. (2016). Prevalence of In- juries in Jiu-Jitsu and Judo Athletes of Portugal South: Associated Injury Mechanisms. J Community Med Health Educ,6:3, http://dx.doi.org./10.4172/216110711.1000441

Oliveira, Pereira (2008). Osteomyoarticular injuries in Judo practitioners Fit Perf J. Nov- Dec;7(6);375-9

Oliveira, TS, Pereira, JS. (2008). Frequency of articulation injuries in judo practicing. Fit Perf J. NovDec;7[6]:375-6.

Pieter, W., De Cre,e C. (1997). Competition injuries in young and adult judo athletes. Abstract book of the Second Annual Congress of the European College of Sport Science. Copenhagen, Denmark:Springer: pp.709-16

Pocecco, E, Ruedl, G., Stankovic, Nq. et al. (2013). Injuries in judo: a systematic literature review including suggestions for prevention. Br J Sports Med;47;1139-11430

Rae, K., Britt H.et all, (2005). Classifying sports medicine diagnoses: a comparison of the International classification of diseases 10-Australian modification (ICD10-AM) and the Orchard sports injury classification system (OSICS-8), Br J Sports Med 2005; 39:907-911. dai:10.1136/bjsm.2004.017517

Souza, M, Monteiro, H, Del Vecchino, F, et al. (2006). Referring to judo's sports injuries in Sao Paulo State Championship. Sci Sports; 21;280-4

Trajković, N., Dejan, M, Maksimović, N., Milošević, Z., Obradović, B. Dimitrova, N., Drid, P. (2018). Evaluating injury risk in female karate athletes: bilateral and unilateral asymmetries of isokinetic strength", 14th International Scientific Conference of Sport Kinetics 2018, "Movement in Human Life and Health", Poreč, Croatia, 24th - 27th June 2018

Zetaruk, M. N., Violan, M.A. et all, (2005). Injuries in martial arts: a comparison of five styles, $\mathrm{Br} J$ Sports Med;39: 29-33. dai: 10.1136/bjsm.2003.010322

Corresponding author:

Anna Nikolova

Department of Sports Medicine National Sports Academy "Vassil Levski Sofia, Bulgaria e-mail: a_lucien@abv.bg 